\title{
Carbon isotopes and lipid biomarker investigation of sources, transport and degradation of terrestrial organic matter in the Buor-Khaya Bay, SE Laptev Sea
}

\author{
E. S. Karlsson ${ }^{1}$, A. Charkin ${ }^{2}$, O. Dudarev ${ }^{2}$, I. Semiletov ${ }^{2,3}$, J. E. Vonk ${ }^{1, *}$, L. Sánchez-García ${ }^{1}$, A. Andersson ${ }^{1}$, and \\ Ö. Gustafsson ${ }^{1}$ \\ ${ }^{1}$ Department of Applied Environmental Science (ITM) and the Bert Bolin Centre for Climate Research, \\ Stockholm University, Sweden \\ ${ }^{2}$ Pacific Oceanological Institute, Russian Academy of Sciences, Vladivostok, Russia \\ ${ }^{3}$ International Arctic Research Center, University Alaska Fairbanks, Fairbanks, AK, USA \\ *now at: ETH Zürich, Geological Institute, Zürich, Switzerland
}

Received: 14 February 2011 - Published in Biogeosciences Discuss.: 31 March 2011

Revised: 22 June 2011 - Accepted: 28 June 2011 - Published: 13 July 2011

\begin{abstract}
The world's largest continental shelf, the East Siberian Shelf Sea, receives substantial input of terrestrial organic carbon (terr-OC) from both large rivers and erosion of its coastline. Degradation of organic matter from thawing permafrost in the Arctic is likely to increase, potentially creating a positive feedback mechanism to climate warming. This study focuses on the Buor-Khaya Bay (SE Laptev Sea), an area with strong terr-OC input from both coastal erosion and the Lena river. To better understand the fate of this terrOC, molecular (acyl lipid biomarkers) and isotopic tools (stable carbon and radiocarbon isotopes) have been applied to both particulate organic carbon (POC) in surface water and sedimentary organic carbon (SOC) collected from the underlying surface sediments.

Clear gradients in both extent of degradation and differences in source contributions were observed both between surface water POC and surface sediment SOC as well as over the $100 \mathrm{~s} \mathrm{~km}$ investigation scale (about 20 stations). Depleted $\delta^{13} \mathrm{C}-\mathrm{OC}$ and high HMW/LMW $n$-alkane ratios signaled that terr-OC was dominating over marine/planktonic sources.

Despite a shallow water column $(10-40 \mathrm{~m})$, the isotopic shift between SOC and POC varied systematically from +2 to +5 per mil for $\delta^{13} \mathrm{C}$ and from +300 to +450 for $\Delta{ }^{14} \mathrm{C}$ from the Lena prodelta to the Buor-Khaya Cape. At the same time,
\end{abstract}

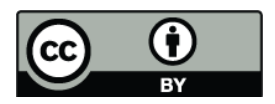

Correspondence to: E. S. Karlsson (emma.karlsson@itm.su.se) the ratio of HMW $n$-alkanoic acids to HMW $n$-alkanes as well as HMW $n$-alkane CPI, both indicative of degradation, were 5-6 times greater in SOC than in POC. This suggests that terr-OC was substantially older yet less degraded in the surface sediment than in the surface waters. This unusual vertical degradation trend was only recently found also for the central East Siberian Sea.

Numerical modeling (Monte Carlo simulations) with $\delta^{13} \mathrm{C}$ and $\Delta^{14} \mathrm{C}$ in both POC and SOC was applied to deduce the relative contribution of - plankton $O C$, surface soil layer OC and yedoma/mineral soil OC. This three end-member dual-carbon-isotopic mixing model suggests quite different scenarios for the POC vs SOC. Surface soil is dominating $(63 \pm 10 \%)$ the suspended organic matter in the surface water of SE Laptev Sea. In contrast, the yedoma/mineral soil OC is accounting for $60 \pm 9 \%$ of the SOC. We hypothesize that yedoma-OC, associated with mineral-rich matter from coastal erosion is ballasted and thus quickly settles to the bottom. The mineral association may also explain the greater resistance to degradation of this terr-OC component. In contrast, more amorphous humic-like and low-density terr-OC from surface soil and recent vegetation represents a younger but more bioavailable and thus degraded terr-OC component held buoyant in surface water. Hence, these two terrOC components may represent different propensities to contribute to a positive feedback to climate warming by converting $\mathrm{OC}$ from coastal and inland permafrost into $\mathrm{CO}_{2}$.

Published by Copernicus Publications on behalf of the European Geosciences Union. 


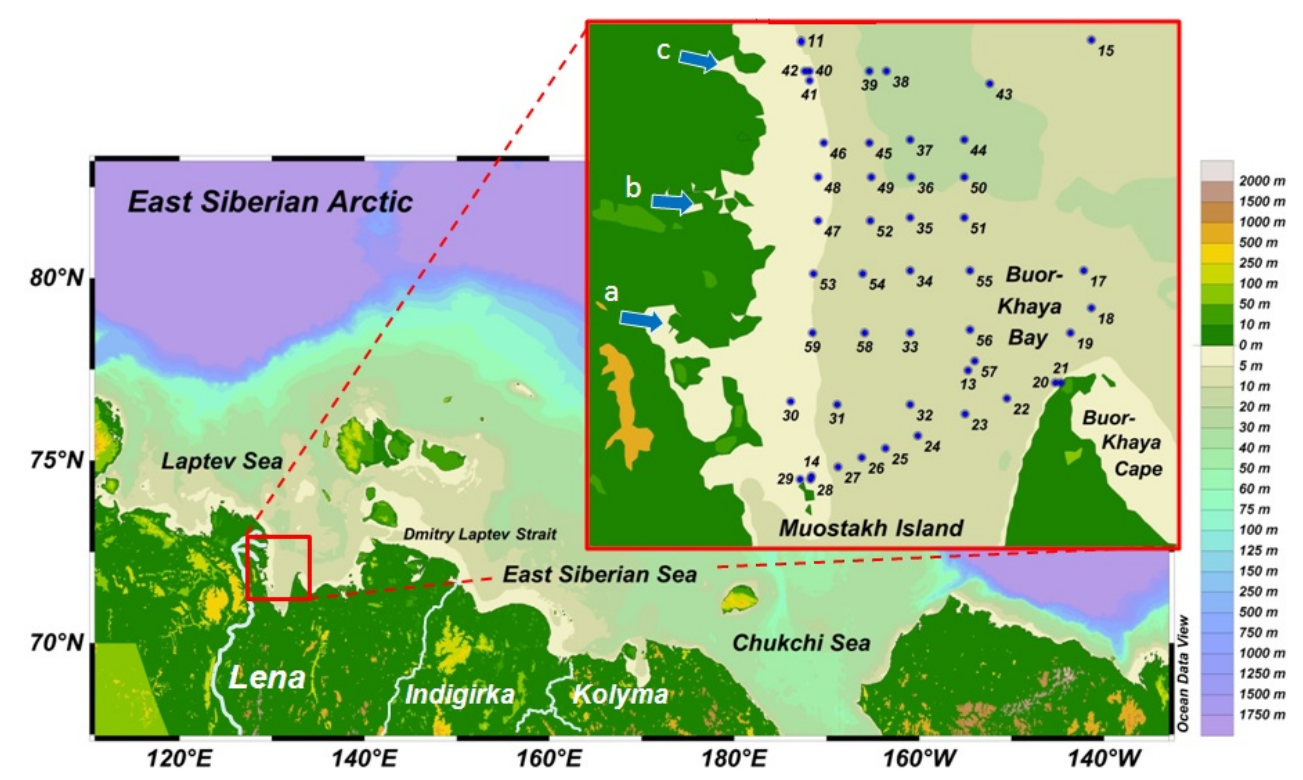

Fig. 1. Map of the East Siberian Arctic Shelf with the Buor-Khaya Bay, South East Laptev Sea detailed in the insert. Exact location and characteristics of sampling stations (blue circles) are given in Table 1 and in the Supplement. The key eastward Lena River delta channels, denoted with blue arrows on insert, are (a): Bykovskaya, (b): Sardahkskaya and (c): Trofimovskaya.

\section{Introduction}

The top few meters of the pan-arctic permafrost holds about half of the global soil organic carbon (OC) (Tarnocai et al., 2009). Amplified warming of the Arctic region (ACIA, 2004; Richter-Menge and Overland, 2010) could bring an increase in release of carbon from permafrost through deepening of the active layer depth, enhanced river bank and coastal erosion, thermokarst formation and opening of deep hydrological flow paths (Schuur et al., 2008; Bense et al., 2009; Frey and McClelland, 2009; Gustafsson et al., 2011). The enhanced warming is particularly pronounced over the landsea region of northeastern Siberia, where both large rivers (e.g., Lena, Yana, Indigirka and Kolyma) and erosion of extensive coastal permafrost held in yedoma (high-OC content loess soil from the Pleistocene) results in substantial input of terrestrial OC (terr-OC) to the extensive East Siberian Arctic Shelf (ESAS: Fig. 1). Soil-OC from thawing permafrost is fluvially released primarily as particulate OC (POC; Guo and Macdonald, 2006; Guo et al., 2007). Coastal erosion of yedoma permafrost also delivers OC mainly in the form of POC to coastal waters (e.g., Semiletov, 1999a, b; Rachold et al., 2000; Stein and Macdonald, 2004). While the fluxes to coastal waters of terr-POC are believed to be roughly equal between rivers and erosion, both fluxes are poorly constrained.

The potential of climate warming to cause conversion of dormant OC, now held in permafrost, into the active carbon cycle with putative degradation to $\mathrm{CO}_{2}$ either on land or in the marine recipient is an important question for the assessment of carbon-climate couplings (e.g., Gruber et al., 2004; IPCC, 2007; McGuire et al., 2009). While there are some estimates of the spatial distribution and erosional disappearance of coastline yedoma (e.g., Semiletov et al., 2005; Dudarev et al., 2003, 2006; Rachold et al., 2000; Stein and MacDonald 2004; Vetrov and Romankevich, 2004; Overduin et al., 2007), there is exceedingly poor knowledge on the fate of this carbon in the marine recipient. Recently, Vonk et al. (2010a) reported that the input from erosion of yedoma/mineral-OC was quantitatively more important than plankton and riverine sources to surface sediment organic matter along a $500 \mathrm{~km}$ offshoreward transect from the mouth of the Kolyma river to the mid-shelf region of the central East Siberian Sea. Several recent studies are now also combining to suggest that the degradation of terr-OC (presumably to $\mathrm{CO}_{2}$ ) in sub-arctic to Arctic shelf systems is more efficient than previously believed (e.g., Semiletov et al., 2007; van Dongen et al., 2008a, b; Vonk et al., 2008; Anderson et al., 2009; Vonk et al., 2010a; Alling et al., 2010; Pipko et al., 2011; Sánchez-García et al., 2011). However, there are also indications that there are very different susceptibilities to degradation of different soil-OC pools (Vonk et al., 2010a, b), complicating the assessment of their role in a positive feedback to climate warming.

This study targets the Buor-Khaya Bay as it is the primary Laptev Sea recipient of terr-OC input from both the Lena River and from erosion of its yedoma-lined coastal bluffs. This SE Laptev Sea region is ideal for seeking to deconvolute the relative importance of different forms of terr-OC from rivers and erosion and to comprehend the transport and 
degradation tendencies of each. The Buor-Khaya Bay is a region of intense coastal erosion (Grigoryev and Kunitsky, 2000; Semiletov, 1999b; Semiletov et al., 2005, 2011; Dudarev et al., 2006; Charkin et al., 2011) and is also where Lena, the largest of the Eurasian-Arctic rivers, is emptying into the coastal Arctic. Molecular tracers and carbon isotopes $\left(\delta^{13} \mathrm{C}\right.$ and $\left.\Delta^{14} \mathrm{C}\right)$ are applied to both surface water particulate organic carbon (POC) and surface sediment organic carbon (SOC) to address the sources and the immediate coastal fate processes (e.g., degradation) of terr-OC.

\section{Study area and methods}

\subsection{The East Siberian Arctic Shelf and Buor-Khaya Bay}

The East Siberian Arctic Shelf (ESAS) consists of the Laptev Sea, East Siberian Sea and the Russian part of the Chukchi Sea, which together constitutes the largest shelf system in the Arctic. The ESAS drainage area is more mountainous, cold and dry to the east where most of the river drainage basins are in the continuous permafrost region (Stein and MacDonald, 2004). The shelf seas bear a heavy riverine imprint from the many large rivers emptying into the ESAS (e.g., Khatanga, Lena, Yana, Indigirka and Kolyma).

The $500 \times 10^{3} \mathrm{~km}^{2}$ Laptev Sea, with an average water depth of just $50 \mathrm{~m}$ (Jakobsson et al., 2008), receives a major portion of its annual discharge from the Lena River $\left(566 \mathrm{~km}^{3}\right.$ out of a total of $745 \mathrm{~km}^{3}$ ) (Cooper et al., 2008). Lena is the largest Arctic river on the Eurasian continent with its source water far south, draining the heterogeneous tundra and taiga with a large portion $(\sim 35 \%)$ of its catchment covering continuous permafrost (Walker, 1998; Stein and Macdonald, 2004; Vetrov and Romankevich, 2004).

The Buor-Khaya Bay located in the SE Laptev Sea (Fig. 1) is an important region for land-sea-atmosphere exchanges. During the partially ice-free summer months, the cold, marine Laptev water meets the warmer, fresh waters of the Lena River that is rich in suspended matter (Vetrov and Romankevich, 2004) causing strongly turbid waters (Dudarev et al., 2006; Charkin et al., 2011). The Buor-Khaya Bay is both the primary recipient of the Lena River discharge and a hotspot for erosion input from coastal yedoma. About $80-90 \%$ of the Lena river water and up to $85 \%$ of its sediment discharge enters the Buor-Khaya Gulf (Dudarev et al., 2006). The two most important Lena delta channels (Fig. 1), on the eastern flank, thus emptying directly into the Buor-Khaya Bay, are the Sardakhsko-Trofimovskaya system (60-75\% of water discharge and up to $70 \%$ of sediment discharge), and the Bykovskaya (20-25\% of water discharge and $15 \%$ of sediment discharge) (Antonov, 1987; Sidorov, 1992).

Up to $30 \%$ of the coastline of the Buor-Khaya Gulf is composed of steep (up to $30 \mathrm{~m}$ ) relief of the yedoma ice complex, which is rapidly collapsing under thermal abrasion and accelerated wind/wave erosion due to the climate warming induced lengthening of the ice-free season and larger wave fetch. For instance, the coastline of Muostakh Island, located in the Buor-Khaya Bay, is retreating on average $11 \mathrm{~m} \mathrm{yr}^{-1}$ (Grigoryev et al., 2000). The ice complex is also widely spread within the Lena River Delta where its average annual retreat rate is $2-3 \mathrm{~m} \mathrm{yr}^{-1}$ (Grigoryev, 1993). Hence, the Gulf's sedimentary and terr-OC material is stemming from two major sources: fluvial sediment discharge from the Lena River and thermal collapse and erosion input from coastal and deltaic yedoma. In addition to strong seasonal variation at these high latitudes, there is a substantial interannual variability in the sediment and terr-OC delivery. Our companion paper Charkin et al. (2011) provides a high-resolution investigation of these temporal dynamics. That paper concludes that there are two dominant types of sediment and terr-POC delivery, with the most common being an erosionaccumulation mode with strong input of terrestrial matter from both river and coastal erosion with a substantial resuspension factor. However, our study period in August 2008 experienced a more unusual accumulation dominated mode with low wind speeds, limited coastal erosion and fluvial discharge into a highly-stratified Buor-Khaya Bay (Charkin et al., 2011).

The Buor-Khaya Bay study area acts as an important integrator of terrestrial matter transformations. The fate of this terrestrial matter even impacts a large part of the East Siberian Sea since the Lena river plume is a dominant vector eastward through the Dmitry Laptev Strait for both water and organic matter from the Buor-Khaya Bay (Semiletov et al., 2005; Alling et al., 2010).

\subsection{Methods}

\subsubsection{Sampling program}

The International Siberian Shelf Study (ISSS-08) took place in August-September 2008. This was an extensive 50day campaign of complex geophysical and hydrogeochemical sampling primarily onboard the H/V Yakob Smirnitskyi (Archangelsk) including at-sea analysis and sub-expeditions extending over the whole East Siberian Shelf Sea (Semiletov and Gustafsson, 2009). A sub-expedition in the Buor-Khaya Bay onboard the vessel TB-0012 sampled (mixed layer) surface water particulate matter (POC) and surface sediment (SOC) in a grid of stations (Fig. 1). Surface water POC was collected at 15 stations (Fig. 1; Table 1) from water volumes of 1.0 to 201 collected in clear polycarbonate flasks. The water was vacuum filtered $(0.25 \mathrm{~atm})$ in an all-glass filtration system, on pre-combusted $\left(12 \mathrm{~h}, 450^{\circ} \mathrm{C}\right)$ glass fiber filters (GF/F $0.7 \mu \mathrm{m}$, Whatman) of $47 \mathrm{~mm}$ or $142 \mathrm{~mm}$ diameters, respectively. The filters were after filtration immediately transferred to pre-combusted aluminum envelopes, frozen and kept at $-18^{\circ} \mathrm{C}$ until analysis. Surface sediment samples were retrieved with a van Veen grab sampler (for 46 stations, Fig. 1). The topmost surface sediment layer was 
Table 1. Organic carbon content, isotopic composition and terrestrial (lipid) biomarker concentrations for surface water particulate organic carbon (POC) and surface sediment organic carbon (SOC) at sampled stations (numbers in top rows; see Fig. 1) in central Buor-Khaya Bay in August 2008.

\begin{tabular}{|c|c|c|c|c|c|c|c|c|c|c|c|c|c|c|c|}
\hline Surface water POC & 11 & 13 & 14 & 15 & & & 19 & 20 & 22 & & 24 & & 26 & & 28 \\
\hline POC $\left(\mu g 1^{-1}\right)$ & 842 & 257 & - & 623 & - & - & 250 & 297 & 316 & - & 245 & - & 292 & - & 372 \\
\hline$\delta 13 \mathrm{C}(\% \circ)$ & -28.0 & -32 & -26.9 & -27.7 & - & - & -30.1 & -29.6 & -29.9 & - & -30.8 & - & -28.7 & - & -29.2 \\
\hline$\Delta 14 \mathrm{C}(\% \circ)$ & -202 & -16 & -374 & - & - & - & -155 & - & - & - & -138 & - & - & - & - \\
\hline $\mathrm{HMW}^{\mathrm{a}} n$-alk $\left(\mu \mathrm{g} \mathrm{g}^{-1} \mathrm{OC}\right)$ & - & - & 100 & 1160 & - & - & 1640 & 793 & 502 & - & 622 & - & 381 & - & 190 \\
\hline $\begin{array}{l}\mathrm{HMW}^{\mathrm{a}} n \text {-alk } \\
\text { acids }\left(\mu \mathrm{gg}^{-1} \mathrm{OC}\right)\end{array}$ & - & - & - & - & - & - & 1980 & 755 & 181 & - & 744 & - & 532 & - & 327 \\
\hline $\mathrm{HMW} / \mathrm{LMW}^{\mathrm{b}} n$-alk & - & - & - & 17.30 & - & - & 1.26 & 1.38 & 4.68 & - & 1.64 & - & 0.723 & - & 1.04 \\
\hline HMW $n$-alk acids $/ n$-alk & - & - & 12.58 & - & - & - & 1.21 & 0.952 & 0.361 & - & 1.20 & - & 1.40 & - & 1.73 \\
\hline$n$-alk CPI $21-31^{\mathrm{c}}$ & - & - & 2.78 & 0.552 & - & - & 0.852 & 0.852 & 0.691 & - & 0.639 & - & 0.706 & - & 0.776 \\
\hline$n$-alk acid CPI $21-32^{\mathrm{c}}$ & - & - & 4.62 & - & - & - & 4.35 & 4.66 & 2.63 & - & 5.30 & - & 4.86 & - & 4.66 \\
\hline Surface sediment SOC & & 13 & 14 & 15 & 17 & 18 & 19 & 20 & 22 & 23 & 24 & 25 & 26 & 27 & 28 \\
\hline $\mathrm{SOC}\left(\mathrm{mg} \mathrm{OC} \mathrm{gdw}^{-1}\right)$ & - & 18.9 & 19.1 & 4.00 & 15.1 & 8.00 & 4.70 & - & 4.00 & - & 18.7 & 18.8 & 20.9 & 19.0 & 21.5 \\
\hline$\delta 13 \mathrm{C}(\% \circ)$ & - & -26 & -26.2 & - & -25.6 & -25.8 & -26.0 & - & -25.3 & -25.8 & -25.6 & -25.8 & -25.8 & -26.0 & -26.2 \\
\hline$\Delta 14 \mathrm{C}(\% \circ)$ & - & -543 & -504 & - & - & - & -622 & - & - & - & -549 & - & - & - & -513 \\
\hline $\begin{array}{l}\mathrm{HMW}^{\mathrm{a}} \quad n \text {-alk } \\
\left(\mu \mathrm{gg}^{-1} \mathrm{OC}\right)\end{array}$ & - & - & - & 132 & 745 & 662 & 810 & - & 628 & 96 & 1060 & 877 & 120 & 3320 & 1090 \\
\hline $\begin{array}{l}\mathrm{HMW}^{\mathrm{a}} n \text {-alk } \\
\text { acids }\left(\mu \mathrm{g} \mathrm{g}^{-1} \mathrm{OC}\right)\end{array}$ & - & - & - & 63.5 & 1330 & 3870 & 1640 & - & 1480 & 7140 & 5020 & 5350 & 916 & - & 5270 \\
\hline $\mathrm{HMW} / \mathrm{LMW}^{\mathrm{b}} n$-alk & - & - & - & 4.52 & 30.7 & 41.1 & 49.5 & - & 16.6 & 15.3 & 45.1 & 33.8 & 15.2 & - & 132.0 \\
\hline HMW $n$-alk acids $/ n$-alk & - & - & - & 0.480 & 1.89 & 6.30 & 4.29 & 0.675 & 2.36 & - & 4.73 & 6.10 & 7.64 & 3.31 & 4.84 \\
\hline$n$-alk CPI $21-31^{\mathrm{c}}$ & - & - & - & 1.55 & 4.43 & 4.62 & 4.32 & 2.73 & 1.88 & 1.31 & 3.57 & 3.56 & 0.873 & 5.55 & 6.31 \\
\hline$n$-alk acid CPI $21-32^{\mathrm{c}}$ & - & - & - & 17.0 & 3.12 & 3.70 & 2.82 & 5.86 & - & - & 3.63 & 3.49 & 2.88 & 4.29 & 3.88 \\
\hline $\begin{array}{l}\text { SOC/POC for } \\
\text { HMW } n \text {-alk acids } / n \text {-alk }\end{array}$ & - & - & - & - & - & - & 3.55 & 0.709 & 6.53 & - & 3.96 & - & 5.47 & - & 2.81 \\
\hline Surface water POC & & 35 & 40 & & 44 & & 47 & 50 & & & & & & & \\
\hline POC $\left(\mu g 1^{-1}\right)$ & - & 442 & 1120 & - & 450 & - & 760 & - & - & - & - & - & & & \\
\hline$\delta 13 \mathrm{C}(\% \circ)$ & - & -24.3 & -29.8 & - & -28.5 & - & -27.3 & -32.2 & - & - & - & - & & & \\
\hline$\Delta 14 \mathrm{C}(\% \circ)$ & - & - & - & - & - & - & - & -199 & - & - & - & - & & & \\
\hline $\begin{array}{l}\mathrm{HMW}^{\mathrm{a}} n \text {-alk } \\
\left(\mu \mathrm{gg}^{-1} \mathrm{OC}\right)\end{array}$ & - & 1600 & 843 & - & 2330 & - & 1340 & - & - & - & - & - & & & \\
\hline $\begin{array}{l}\mathrm{HMW}^{\mathrm{a}} \quad n \text {-alk } \\
\text { acids }\left(\mu \mathrm{gg}^{-1} \mathrm{OC}\right)\end{array}$ & - & 493 & 402 & - & & - & 1410 & - & - & - & - & - & & & \\
\hline HMW/LMW ${ }^{\mathrm{b}} \quad n$-alk & - & 11.1 & 10.8 & - & 12.7 & - & 10.6 & - & - & - & - & - & & & \\
\hline HMW $n$-alk acids/ $n$-alk & - & 0.309 & 0.478 & - & & - & 1.05 & - & - & - & - & - & & & \\
\hline$n$-alk CPI $21-31^{\mathrm{c}}$ & - & 0.295 & 0.336 & - & 0.346 & - & 0.332 & - & - & - & - & - & & & \\
\hline$n$-alk acid CPI $21-32^{\mathrm{c}}$ & - & 10.0 & 7.28 & - & - & - & - & - & - & - & - & - & & & \\
\hline Surface sediment SOC & 30 & 35 & 40 & 43 & 44 & 46 & 47 & 50 & 51 & 53 & 54 & 59 & & & \\
\hline $\mathrm{OC}\left(\mathrm{mg} \mathrm{OC} \mathrm{g} \mathrm{dw} w^{-1}\right)$ & 20.4 & 23.0 & 15.0 & 15.6 & 20.9 & 25.8 & 38.1 & 18.2 & 21.4 & 96.0 & 8.8 & 18.7 & & & \\
\hline$\delta 13 \mathrm{C}(\% \circ)$ & -26.0 & -26.0 & -26.0 & -25.6 & -25.9 & -26.5 & - & -25.7 & -25.8 & -27.5 & -25.7 & -26.0 & & & \\
\hline$\Delta 14 \mathrm{C}(\% \circ)$ & - & - & - & -517 & - & -436 & - & - & -495 & - & - & - & & & \\
\hline $\begin{array}{l}\mathrm{HMW}^{\mathrm{a}} n \text {-alk } \\
\left(\mu \mathrm{g} \mathrm{g}^{-1} \mathrm{OC}\right)\end{array}$ & 604 & 729 & 768 & 734 & 792 & 446 & 458 & - & 947 & 362 & 637 & 711 & & & \\
\hline $\begin{array}{l}\mathrm{HMW}^{\mathrm{a}} n \text {-alk acids } \\
\left(\mu \mathrm{g} \mathrm{g}^{-1} \mathrm{OC}\right)\end{array}$ & 3540 & 1420 & 5750 & 1880 & 2050 & 4570 & 1630 & 2840 & 457 & 1560 & 2940 & 3750 & & & \\
\hline HMW/LMW ${ }^{\mathrm{b}} \quad n$-alk & 33.3 & 25.4 & 22.4 & 34.4 & 21.4 & 15.4 & 18.5 & 48.6 & 70.9 & 16.9 & 30.5 & 31.9 & & & \\
\hline HMW $n$-alk acids/ $n$-alk & 5.86 & 1.94 & 7.75 & 2.57 & 2.59 & 10.7 & 3.73 & 4.56 & 0.480 & 4.64 & 4.62 & 5.27 & & & \\
\hline$n$-alk CPI $21-31^{\mathrm{c}}$ & 6.34 & 4.88 & 5.95 & 4.70 & 4.81 & 4.57 & 5.20 & - & 5.78 & 5.46 & 0.410 & 5.73 & & & \\
\hline$n$-alk acid CPI $21-32^{\mathrm{c}}$ & 4.22 & 3.90 & 4.22 & 3.80 & 3.67 & 4.09 & 3.47 & 3.81 & 2.10 & 3.48 & 4.16 & 3.64 & & & \\
\hline $\begin{array}{l}\text { SOC/POC for } \\
\text { HMW } n \text {-alk acids } n \text {-alk }\end{array}$ & - & 6.29 & 16.2 & - & - & - & 3.55 & - & - & - & - & - & & & \\
\hline
\end{tabular}

${ }^{\mathrm{a}} \mathrm{HMW}$ is high molecular weight, sum of $\mathrm{C}_{20}-\mathrm{C}_{34}$ for $n$-alkanes and $\mathrm{C}_{20}-\mathrm{C}_{30}$ for $n$-alkanoic acids. ${ }^{\mathrm{b}}$ LMW is low molecular weight, sum of $n$-alkane concentrations of $\mathrm{C}_{17}-\mathrm{C}_{19}$. ${ }^{\mathrm{c}} \mathrm{CPI}$ is the carbon preference index, calculated as $1 / 2 \sum\left(X_{i}+X_{i+2}+\ldots+X_{n}\right) / \sum\left(X_{i-1}+X_{i+1}+\ldots+X_{n-1}\right)+{ }^{1} / 2 \sum\left(X_{i}+X_{i+2}+\ldots+X_{n}\right) / \sum\left(X_{i+1}+X_{i+3}+\ldots+X_{n+1}\right)$, where $X$ is concentration. 
transferred with stainless steel spatulas to polyethylene containers before being stored at $-18^{\circ} \mathrm{C}$ until analysis.

\subsubsection{Bulk elemental and isotope analysis}

After freeze drying (Christ Alpha 2-4, LSC; Vacuum hybrid pump, Vacubrand RC-6; Martin Christ, Labex Instrument $\mathrm{AB}$ ) between 8.9 and $22 \mathrm{mg}$ of homogenized and ground sediment for each station was weighed into pre-combusted silver capsules $(5 \times 9 \mathrm{~mm}$, Säntis Analytical AG, Teufen, Switzerland) and acidified in situ with $50 \mu \mathrm{l} 1 \mathrm{M} \mathrm{HCl}$ for removal of carbonates and dried over night in $60^{\circ} \mathrm{C}$ following procedure adapted from Gustafsson et al. (1997). A similar procedure of in situ acidification and subsequent drying in silver capsules $(5 \times 12 \mathrm{~mm})$ was followed for POC on sub-sampled GF/F filters (8-12 punches of $5 \mathrm{~mm}$ ). Acidified POC samples were analyzed in triplicates for organic carbon content and its $\delta^{13} \mathrm{C}$ composition using isotope ratio mass spectrometer (Europa Hydra 20/20, University of California, Davis, Stable Isotope Facility, Davis, CA, USA). SOC $\delta^{13} \mathrm{C}$ was measured at Stockholm University (Department of Geological Sciences) with a Carlo Erba NC2500 elemental analyzer connected via a split interface to a Finnigan MAT Delta Plus mass spectrometer.

Another sub sampled set of the GF/F filters and freezedried surface sediments were after similar acidification and drying analyzed for its radiocarbon content $\left(\Delta^{14} \mathrm{C}\right)$. The accelerator mass spectrometry analysis for $\Delta^{14} \mathrm{C}$ was performed at the National Ocean Sciences Accelerator Mass Spectrometry (NOSAMS) facility at Woods Hole Oceanographic Institution (WHOI, Woods Hole, MA, USA).

\subsubsection{Lipid extraction and cleanup process}

Homogenized surface sediment and surface water GF/F filters were extracted and the extracts purified as detailed earlier (e.g., van Dongen et al., 2008b; Vonk et al., 2008). Briefly, samples were extracted in dichloromethane:methanol (DCM: $\mathrm{MeOH} 2: 1 \mathrm{v} / \mathrm{v}$ ) using Soxhlet for $24 \mathrm{~h}$. Extracts (total lipid extracts) were concentrated, cleaned up and separated into acid, hydrocarbon and polar fractions through Bond-Elut ${ }^{\circledR}$ separation and column chromatography over $\mathrm{Al}_{2} \mathrm{O}_{3}$. Quantification and recoveries were controlled with internal standards $\left(\mathrm{D}_{50}\right.$-tetracosane, $\mathrm{D}_{39}$-eicosanoic acid, 2-hexadecanol and $\mathrm{D}_{12}$-chrysene). The hydrocarbon fractions were eluted through (10\% deactivated) silica columns prior to instrumental analysis.

Anticipated Bond-Elut ${ }^{\circledR}$ column bleeding (Russel and Werne, 2007) was detected by contamination of $\mathrm{C}_{16}$ and $\mathrm{C}_{18} \quad n$-alkanoic acids in laboratory blanks (those are not target analytes in this study). No significant contaminations of target analytes were recorded. Recovery yields ranged from 0.59 to 0.81 (mean $0.69 \pm 0.11$ ).

\subsubsection{Instrumental analysis}

The isolated hydrocarbon, polar and acid fractions were analyzed separately with gas chromatography mass spectrometry (GC-MS) using an $8060 \mathrm{GC}$ interfaced to an MD 800 MS (Fisons PLC, Ipswich, Suffolk, UK). The MS was operating at $70 \mathrm{eV}$ and scanning an $\mathrm{m} / \mathrm{z}$ range of 50 600. The analytes were injected on-column to a PTE5 (Supelco Inc, Bellefonte, Pennsylvania, USA) capillary column $(30 \mathrm{~m}, 0.25 \mathrm{~mm}$ diameter, $5 \%$-diphenyl-dimethylpolysiloxane film, of $0.25 \mu \mathrm{m}$ thickness). The transfer line was kept at $300^{\circ} \mathrm{C}$ and the ion source at $240^{\circ} \mathrm{C}$. Acid and polar fractions were derivatized with $\mathrm{BF}_{3}-\mathrm{MeOH}$ and BSTFA, respectively, prior to analysis. The detailed GC temperature program followed Vonk et al. (2008).

\subsubsection{Monte Carlo simulations}

The applied End-member mixing model analysis (EMMA), between three sources (yedoma/mineral soil, plankton and surface soil) of both surface water POC and surface sediment SOC in Buor-Khaya Bay using two carbon isotopic signatures $\left(\delta^{13} \mathrm{C}, \Delta{ }^{14} \mathrm{C}\right)$ as source markers may be formalized as:

$$
\begin{aligned}
f_{\text {plankton }}+ & f_{\text {surface soil }}+f_{\text {yedoma, mineral soil }}=1 \\
\delta^{13} \mathrm{C}_{\text {sample }}= & f_{\text {plankton } \delta} \delta^{13} \mathrm{C}_{\text {plankton }}+f_{\text {surface soil } \delta} \delta^{13} \mathrm{C}_{\text {surface soil }} \\
& +f_{\text {yedoma, }} \text { mineral soil } \delta{ }^{13} \mathrm{C}_{\text {yedoma, mineral soil }}
\end{aligned}
$$

$$
\begin{aligned}
\Delta{ }^{14} \mathrm{C}_{\text {sample }}= & f_{\text {plankton }} \Delta{ }^{14} \mathrm{C}_{\text {plankton }}+f_{\text {surface soil }} \Delta{ }^{14} \mathrm{C}_{\text {surface soil }} \\
& +f_{\text {yedoma, }} \text { mineral soil } \Delta{ }^{14} \mathrm{C}_{\text {yedoma, }} \text { mineral soil }
\end{aligned}
$$

Where $f_{\text {plankton}}, f_{\text {surface soil }} f_{\text {yedoma, mineral soil }}$ are the fractions of plankton, surface soil and yedoma/mineral soil OC contributions to each sample.

In order to account for source variability in the endmember values a random sampling Monte Carlo approach was implemented, as was previously described in Vonk et al. (2010a). Briefly, the variability of each source marker was modeled using a normal distribution, with mean and standard deviation defined by literature and estimates of ISSS-08 data described in Vonk et al. (2010a). Solutions for the system of Eqs. (1-3) were generated by random sampling from these distributions, while constraining the solutions to be between one and zero (i.e., fractional contributions). These were then sorted into histograms, forming probability density functions (PDFs) for the fractional solutions. From the PDFs the mean relative source contributions and the standard deviations were calculated. The end-member values were represented using normal distributions. A log-normal distribution was also tested (Supplement Fig. S1) but the discrepancy between the two fits lies well within their uncertainty.

The end-member values used for plankton OC was: $\delta^{13} \mathrm{C}$ $-24.0 \pm 1 \%$ o, $\Delta{ }^{14} \mathrm{C} 25 \pm 25 \%$, where the variation indicates the standard deviation. The plankton $\delta^{13} \mathrm{C}$ end-member 
was chosen accounting the impact of terrestrial OC degradation on the signature of dissolved $\mathrm{CO}_{2}$ in the water column (Sánchez-García et al., 2011). The $\Delta^{14} \mathrm{C}$ value is taken from the Bering Strait, Northern Pacific (Key et al., 2004) in lack of comparable POC measurements from the ESAS and SE Laptev Sea. For surface soil OC the end-member values were defined by: $\delta^{13} \mathrm{C}-32.1 \pm 1.5 \% \circ(n=8)$ and $\Delta^{14} \mathrm{C}-85 \pm 62 \%$ o $(n=7)$. The $\delta^{13} \mathrm{C}$ end-member is taken from $\delta^{13} \mathrm{C}_{\mathrm{POC}}$ data in Kolyma River tributaries draining mostly non-yedoma ground (July 2010, Polaris expedition, $\mathrm{J}$. Vonk et al., unpublished data. The $\Delta^{14} \mathrm{C}$ value is combined from literature data on surface peat/soil (Goni et al., 2005; Xu et al., 2009; Porcelli et al., 1997; Guo et al., 2007) and POC near Kolyma river mouth $(n=2$, Vonk et al., 2010). yedoma/mineral soil OC end-member values used were: $\delta^{13} \mathrm{C}-25.8 \pm 1.7 \%$ o $(n=26), \Delta^{14} \mathrm{C}-788 \pm 201 \%$. $(n=22)$, (Dutta et al., 2006; Sánchez-García et al., 2011), described in detail in Vonk et al. (2010a).

The MC simulations used 100000 sampled values within the given frame (Eqs. 1-3) and were sorted in histograms of bin size 256. The MC computer simulation strategy was performed in Matlab version 7.9.0 (Math Works, Natick, USA).

\section{Results and discussion}

\subsection{Spatial distribution of organic carbon and terrestrial biomarkers}

High organic carbon contents were found in this near-coastal system as expected from the strong influence by both river and erosion sources. The surface water POC ranges from 245 to $1120 \mu \mathrm{g}^{-1}$ (mean of $470 \mu \mathrm{g}^{-1}$ ) (Fig. 2a; Table 1). These POC levels can be compared with levels of $300 \mu \mathrm{g}^{-1}$ reported for SE Laptev Sea in 2008 from another ship (Sanchéz-García et al., 2011). The stations closest to the coast in the central East Siberian Sea for the Kolyma paleoriver study showed levels of surface water POC of 200$300 \mathrm{\mu g}^{-1}$ (Vonk et al., 2010a). The highest concentrations in the present study were in the vicinity of Lena delta channel mouths while lower concentrations were found in the Buor-Khaya Bay closer to the yedoma coastline (Fig. 2a). This is consistent with the accumulation mode of sediment delivery in summer of 2008 as detailed by Charkin et al. (2011), where the fluvial source was dominating over erosional sources.

The Buor-Khaya Bay SOC ranges from 4.0 to $96 \mathrm{mg} \mathrm{gdw}^{-1}$ (mean of $21 \mathrm{mg} \mathrm{gdw}^{-1}$ ) (Fig. 2b; Table 1). This is in the upper range of what has been previously reported for the ESAS (Dudarev et al., 2003; Stein and McDonald, 2004; Semiletov et al., 2005). Van Dongen et al. (2008) reports Eurasian Arctic estuarine surface SOC between 4.8 and $19 \mathrm{mggdw}^{-1}$, and in the recent study of the Kolyma paleoriver surface sediments SOC ranged $8-14 \mathrm{mg} \mathrm{gdw}^{-1}$ (Vonk et al., 2010a). The spatial distribution of the SOC was different from the 2008 surface water POC. There was a clear gradient in SOC concentration from west to east in the Buor-Khaya Bay with highest concentrations off Lena River and erosion sites in the SW Bay such as Muostakh Island. High-molecular weight (HMW) $n$-alkanes (here, sum of $\mathrm{C}_{20}-\mathrm{C}_{34}$; individual $n$-alkanes reported in Supplement Tables S1 and S2 for POC and SOC, respectively) are produced by terrestrial plants (Eglinton and Hamilton, $1967)$ and thus a signal for terr-OC ( $n$-alkanes in plankton have shorter chain lengths). The concentration of HMW $n$-alkanes in surface water POC was clearly lower in SW Buor-Khaya Bay and higher near the Lena outflow with a plume, containing a maximum $\left(2.3 \mathrm{mg} \mathrm{g}^{-1} \mathrm{OC}\right)$, toward the northeast (Fig. 2c). The HMW $n$-alkane concentration in SOC was 0.1 to $3.3 \mathrm{mg} \mathrm{g}^{-1}$ OC (Table 1; Fig. 2d), which is in same range as previously reported $0.55 \mathrm{mg} \mathrm{g}^{-1} \mathrm{OC}$ outside the Lena river mouth (van Dongen et al., 2008a). The spatial distribution in sediment SOC is markedly different than in the POC with highest concentrations in SW Buor-Khaya Bay around the active coastal erosion sites, and the lowest in the NE (Fig. 2d). Clearly, the proximity to Muostakh Island carries the higher end of the range $\left(3.3\right.$ and $1.2 \mathrm{mgg}^{-1}$ OC). This distribution of HMW $n$-alkanes is consistent with the two sedimentation regimes suggested in Charkin et al. (2011) with an accumulation (riverine) source dominating the surface water in August 2008 whereas the longer-term integrating sediments show a strong contribution also from coastal erosion.

\subsection{Marine versus terrestrial sources}

There is a dominant terrestrial contribution to both surface water POC and surface sediment SOC in the whole bay. The surface water $\delta^{13} \mathrm{C}_{\mathrm{POC}}$ spans over a wide range from -32.2 to $-24.3 \%$ with a quite depleted mean of $-29.1 \pm 2.0 \%$ o $(n=15)$. There is a gradient in $\delta^{13} \mathrm{C}_{\mathrm{POC}}$ with values off the eastern Lena delta at about $-27 \%$, consistent with previous reports (Naidu et al., 2000; Semiletov, 1999a, b, 2011) with more depleted values in the central Buor-Khaya Bay (Fig. 2e). The depleted ${ }^{13} \mathrm{C}_{\mathrm{POC}}$ in surface waters of 2008 , which are lower than for other years (Charkin et al., 2011), likely reflect phytoplankton and their debris. Photosynthesis that has occurred in the river is known to produce depleted ${ }^{13} \mathrm{C}$ (Rachold et al., 1999; Semiletov et al., 2011). The depleted ${ }^{13} \mathrm{C}_{\mathrm{POC}}$ is also consistent with coastal primary production using excess fluvial dissolved inorganic carbon (DIC) carrying a depleted ${ }^{13} \mathrm{C}$ relative to marine DIC - thus creating a negative bias. This latter mechanism was hypothesized to explain similarly depleted ${ }^{13} \mathrm{C}_{\mathrm{POC}}$ in the distant Lena plume far offshore in the Laptev and East Siberian Sea that also matched with depletion of other nutrients (Alling et al., 2010; Sánchez-García et al., 2011).

There is a more homogeneous distribution of $\delta^{13} \mathrm{C}_{\mathrm{SOC}}$ that likely reflects averaging over a longer time in the surface sediment regime (Fig. 2f). The $\delta^{13} \mathrm{C}_{\mathrm{SOC}}$ ranges from -27.5 to 

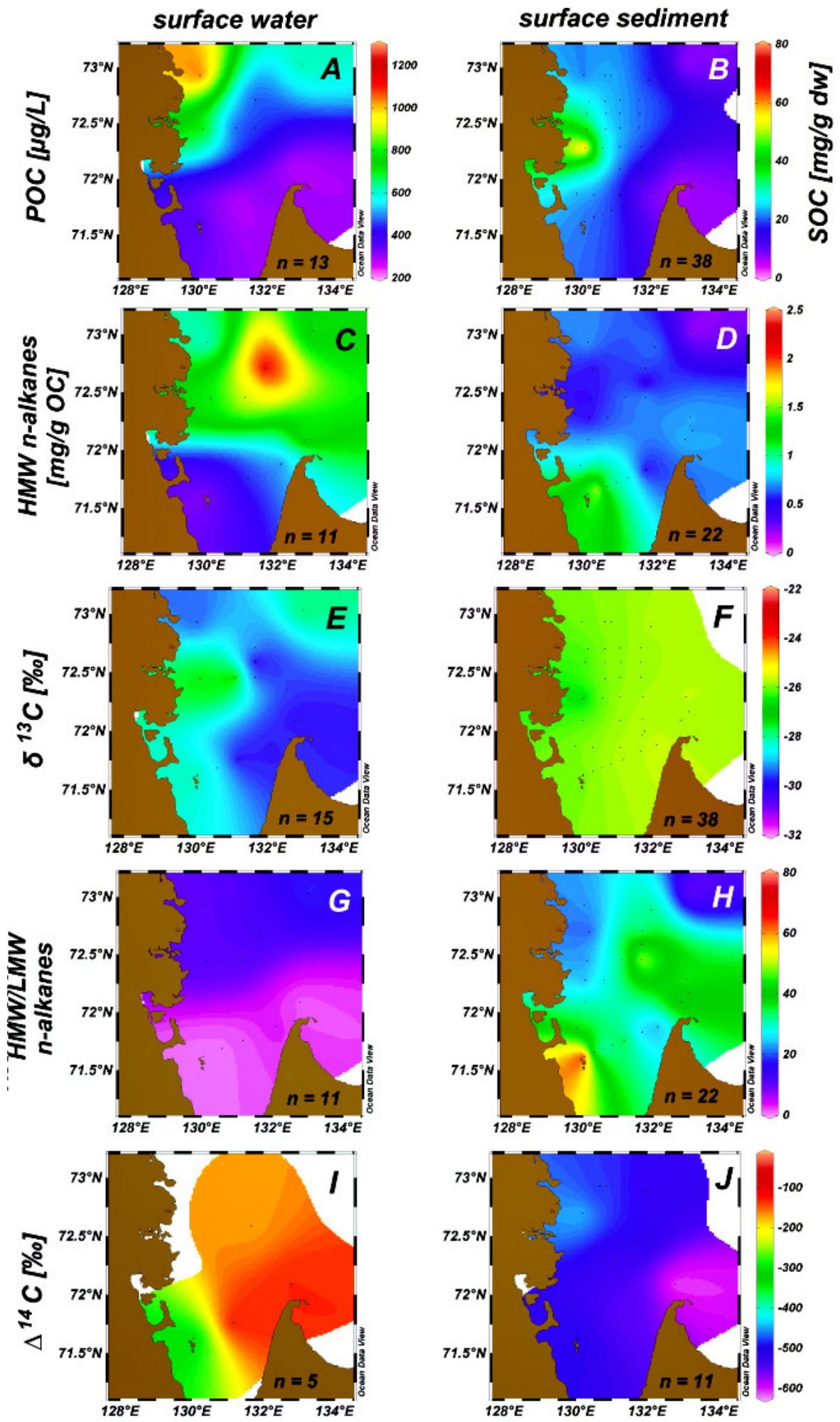

Fig. 2. Spatial distribution of organic carbon concentrations and characteristics possibly diagnostic of sources in the Buor-Khaya surface water particles (left column) and surface sediment (right column) in August 2008. $n$ refers to the number of stations the parameter extrapolation is based upon. (A) particulate organic carbon, (POC) $\left(\mu \mathrm{g} 1^{-1}\right)$; (B) surface sediment organic carbon (SOC) (mg g ${ }^{-1} \mathrm{dw}$; (C) and (D) the sum of high molecular weight (HMW) $n$-alkanes, i.e. the sum of chain lengths $\mathrm{C}_{20}-\mathrm{C}_{34}$ in POC and SOC, respectively (mg g ${ }^{-1} \mathrm{OC}$ ); (E) $\delta^{13} \mathrm{C}_{\mathrm{SOC}}(\%)$; (F) $\delta^{13} \mathrm{C}_{\mathrm{POC}}(\%)$; (G) and (H) HMW/LMW $n$-alkanes, where LMW is low molecular weight, i.e. sum of $\mathrm{C}_{17}-\mathrm{C}_{19}$ in POC and SOC, respectively; (I) $\Delta^{14} \mathrm{C}_{\mathrm{POC}}(\%) ;(\mathbf{J}) \Delta^{14} \mathrm{C}_{\mathrm{SOC}}(\%)$. 

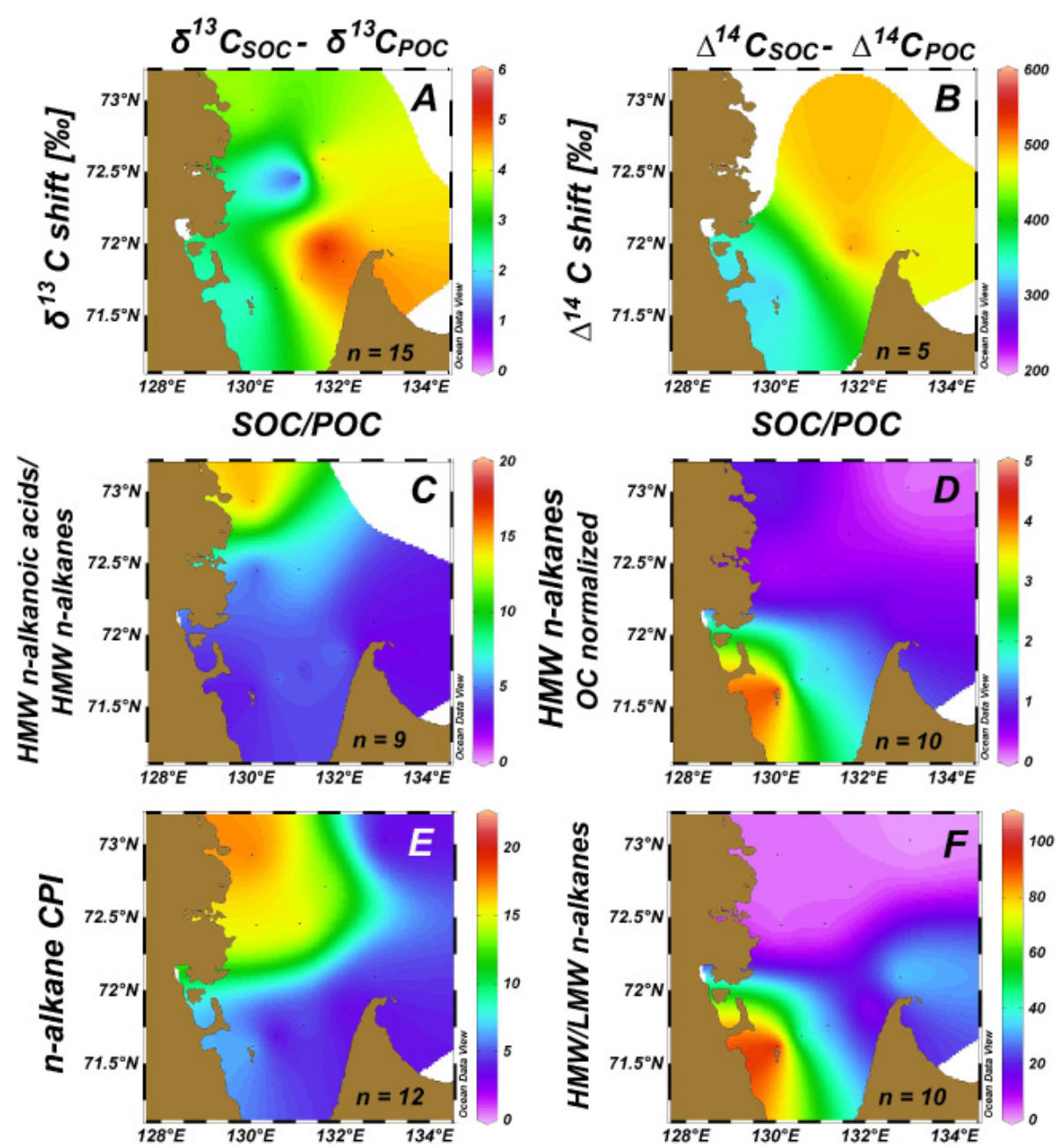

Fig. 3. Spatial distribution in the Buor-Khaya Bay of shift in carbon isotopic and lipid biomarker signals between surface water (POC) and surface sediments (SOC) in August 2008. (A) $\delta^{13} \mathrm{C}_{\mathrm{SOC}}-\delta^{13} \mathrm{C}_{\mathrm{POC}}\left(\%\right.$ ); (B) $\Delta^{14} \mathrm{C}_{\mathrm{SOC}}-\Delta^{14} \mathrm{C}_{\mathrm{POC}}(\%)$; (C) (HMW

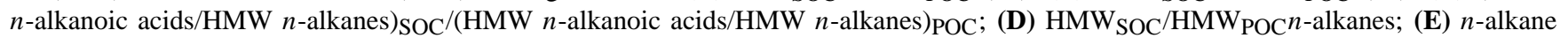
$\mathrm{CPI}_{\mathrm{SOC}} / \mathrm{CPI}_{\mathrm{POC}}(\mathbf{F})(\mathrm{HMW} / \mathrm{LMW})_{\mathrm{SOC}} /(\mathrm{HMW} / \mathrm{LMW})_{\mathrm{POC}} n$-alkanes.

$-25.0 \%$ (Table 1) with a mean of $-25.9 \pm 0.42 \%$ o $(n=22)$. There is a weak gradient of slightly more depleted values near the river outflow and slightly more enriched values elsewhere (e.g., near the erosion regimes around Buor-Khaya Cape (Fig. 2f). Studies of yedoma erosional surfaces have reported $\delta^{13} \mathrm{C}_{\mathrm{OC}}$ values generally in the range of -24 to $-27 \%$ (e.g., Schirrmeister et al., 2002; Stein and Macdonald, 2004; Dutta et al., 2006).

Taken together, the SOC is substantially more enriched in ${ }^{13} \mathrm{C}$ than the POC $\left({ }^{13} \mathrm{C}\right.$ shift from SOC to POC - Fig. 3a). The ${ }^{13} \mathrm{C}$ shift spans from $2-3 \%$ in the shallow prodelta to reach $4-5 \%$ in the central and eastern bay near the BuorKhaya Cape.

The acyl lipid biomarker composition offers a complementary angle on the relative contribution of terrestrial versus marine sources. The imprint of terrestrial HMW $\left(\geq \mathrm{C}_{21}\right)$ to marine LMW $\left(\mathrm{C}_{17}+\mathrm{C}_{19}\right) n$-alkanes in POC ranges from
0.72 to 17 (mean of $6.7 \pm 4.7$; Table 1 ; Fig. $2 \mathrm{~g}$ ). An even stronger terrestrial signal is apparent in SOC with the same ratio ranging from 4.5 to as high as 130 (mean of 34; Table 1, Fig. 2h). While this molecular information suggests there may be a (minor) planktonic contribution to POC, it suggests that the SOC is nearly exclusively of terrestrial origin.

A HMW/LMW $n$-alkane ratio toward the lower end of this range has been reported for a single SOC station off the Lena river mouth (e.g., TAR $n$-alkane at 17 ) by van Dongen et al. (2008a). The vast difference between POC and $\mathrm{SOC}$ is in line with the picture from the Kolyma paleoriver transect where HMW/LMW $n$-alkane values in SOC reaches up above 50 but is below 5 for surface water POC near the Kolyma river mouth. Beside/despite the great distinction between the two, these values still reveal an overwhelmingly terrestrial imprint in Buor-Khaya Bay. 


\subsection{Surface soils versus mineral/yedoma soils}

Natural abundance radiocarbon $\left(\Delta^{14} \mathrm{C}\right)$ presents a possibility to distinguish the relative contributions of terr-OC from surface soils, exported mainly by the rivers, from mineral/yedoma soil, remobilized largely through erosion of the coastline. yedoma is of Pleistocene age (e.g., Romanovskii, 1993; Grigoriev, 1993; Schirrmeister et al., 2002; Overduin et al., 2007) and thus depleted in radiocarbon content while the annual thaw layer with its vegetation are releasing younger organic matter from the drainage basin. Riverine organic matter is thus a combination of such more freshly produced organic matter and older material from thermokarst collapse and erosion of riverbanks and coastal/deltaic yedoma. Analysis of $\Delta^{14} \mathrm{C}$ of $\mathrm{OC}$ in BuorKhaya Bay reveals that surface water $\Delta^{14} \mathrm{C}_{\mathrm{POC}}$ (Fig. 2i) is much more enriched than underlying surface sediment $\Delta^{14} \mathrm{C}_{\text {SOC }}$ (Fig. 2j). The $\Delta^{14} \mathrm{C}_{\mathrm{POC}}$ ranges from -374 to $-16 \%$ (mean $-176 ; n=6$ ) whereas the $\Delta^{14} \mathrm{C}$ soC ranges from -611 to $-436 \%$ o (mean $-524 ; n=8$ ) and (Table 1 ). There is a strong gradient in $\Delta^{14} \mathrm{C}_{\mathrm{POC}}$ from below $-300 \%$ o in the erosion-influenced SW corner of the Buor-Khaya Bay to around zero in the open Laptev Sea. This perhaps indicates younger surface soil and planktonic matter in a mixture, with an increasing portion of older coastal erosion matter towards the active erosion site in the SW of the bay. In sharp contrast, the surface sediment OC is much more depleted in 14C. The $\Delta{ }^{14} \mathrm{C}_{\mathrm{SOC}}$ goes from $-436 \%$ off the Trofimovskaya delta channel to even lower values eastward and down to $-600 \%$ o in the Buor-Khaya Cape region (Fig. 2j). Hence, there is a very large $\Delta^{14} \mathrm{C}$ shift from POC to SOC of 130 to $526 \%$ o (Fig. 3b) corresponding to an age difference of 1870 to 6150 $14 \mathrm{C}$ yr, respectively, in this $10-40 \mathrm{~m}$ shallow water column. This is comparable to the difference between POC and SOC in the East Siberian Sea (Vonk et al., 2010a).

It has recently been argued that the fluvial organic matter is exported in two physical forms; (i) as organic-rich lowdensity flocs that stay suspended over long distances and (ii) as organic coatings on mineral particles, which are more rapidly settling out (Vonk et al., 2010a, b). The $\delta^{13} \mathrm{C}$ of surface sediments are consistent with a heavier $\delta^{13} \mathrm{C}$ fraction settling out to balance the depleted $\delta^{13} \mathrm{C}$ being transported further offshore with surface waters. The mineral ballasted $\mathrm{OC}$ form is likely to originate from mineral soils such as yedoma, whereas the low-density OC-rich humic floc may reflect $\mathrm{OC}$ origin in the annual thaw layer and recent vegetation. Such a mechanism is also consistent with the much higher $14 \mathrm{C}$ ages of SOC stemming relatively more from erosional sources.

\subsection{Quantitative source apportionment of sedimentary OM}

The dual-carbon isotope data allow differentiating the relative contribution of plankton, surface soil and yedoma/mineral-soil to the OC in the coastal Laptev system. The stable carbon isotopic signatures help to separate terrestrial from marine sources, yet the $\delta^{13} \mathrm{C}$ end-member values of the two terrestrially-derived sources, yedoma/mineral soil OC and surface soil OC, are overlapping. Simultaneous measurements of the natural abundance radiocarbon signal offer the possibility to separate these two terrestrial sources. yedoma soil OC consists of old freeze-locked loess soil deposits of Pleistocene age, whereas surface soil organic carbon represents younger material (e.g., Neff et al., 2006) from the annual thaw layer of permafrost and peat deposits that have been biosynthesized between the present and the early Holocene (Macdonald et al., 2006). The advantage of the MC source apportionment simulation is that it accounts for variability in the end member values (see Methods) and thus provides a statistical description of the precision of the source apportionment calculations. The MC dual carbon $\left({ }^{13} \mathrm{C}, \Delta{ }^{14} \mathrm{C}\right)$ source apportionment approach is here applied to both surface SOC and, for the first time, also to surface water POC. Remarkably different source contributions were recorded for POC versus the SOC underlying the $10-25 \mathrm{~m}$ shallow water column of the BK Bay.

The source apportionment calculations suggest that the relative contributions to the POC fractions are 7.0-32\%, $26-83 \%$ and $3.0-46 \%$ for plankton, surface soil and yedoma/mineral-soil derived OC respectively (Fig. 4a; Table 2). Station 14 stands out with $46 \%$ of the POC coming from yedoma, $29 \%$ from plankton OC and $26 \%$ from surface soil OC, which can be explained by its location, right off the northernmost point of the eroding Muostakh Island (Fig. 1). To be noted is also the decrease in yedoma derived material to the POC with increasing water depth, which is followed by the opposite trend of surface soil OC rising heavily as the yedoma OC fraction drops. This reduction in yedoma OC with depth confirms the hypothesis of mineral-rich material from coastal erosion being slumped out and sinking/settling quickly to the bottom.

The picture in the water column is markedly different from that in the sediment. Calculated surface sediment SOC contributions were 16-37\% from plankton OC, 8.0-20\% from surface soil and 53-71\% from yedoma/mineral soil OC (Fig. 4b; Table 2). The plankton fraction of the surface water POC is lower than in the sediment SOC. The high surface soil fraction in POC in 2008 could reflect the anomalously high relative input from the river compared with from erosion in that particular year (Charkin et al., 2011). As samples from the water column are snap shots while sedimentary records include earlier events and the aftermath of several processes, the POC is anticipated to carry a more seasonal bound (interannually variable) composition. The significantly smaller imprint in the sediment OC possibly reflects a strong ongoing degradation of the more bioavailable organic-rich OC flocs being carried by the river suspended matter.

Overall, the source contribution to the POC fractions changes with water depth, reflecting the effect of preferential 


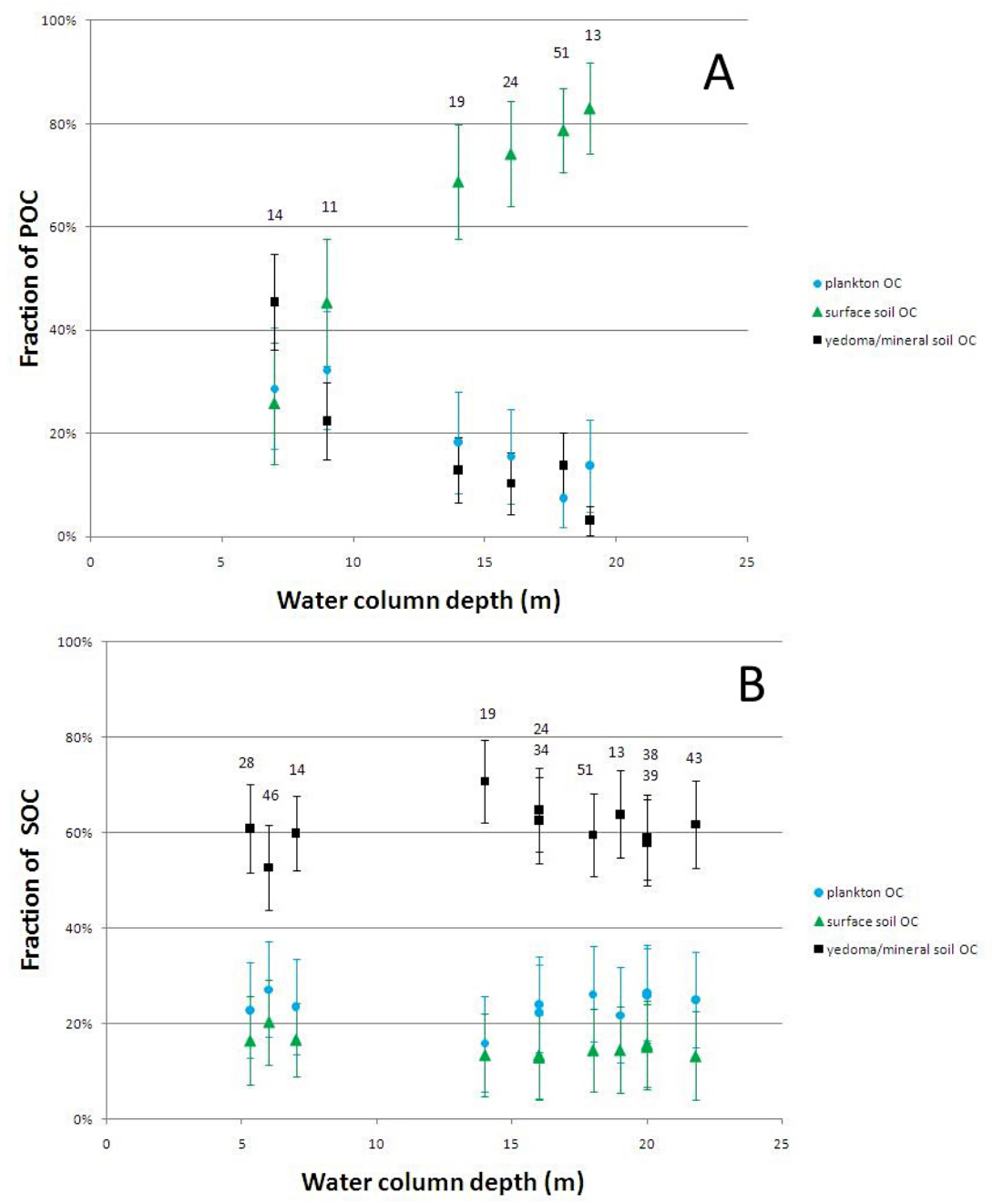

Fig. 4. Results of three end-member mixing model (Monte Carlo simulation) analysis of relative contributions from marine plankton ( $f_{\text {plankton}}$; blue circles), surface soil ( $f_{\text {surfsoil }}$; green triangles $)$ and old yedoma/mineral soil ( $f_{\text {yedoma/mineral soil }}$; black squares $)$ to $(\mathbf{A})$ surface water particulate organic carbon (POC) and (B) surface sediment organic carbon (SOC) in Buor-Khaya Bay in August 2008.

settling of the heavier mineral bound $\mathrm{OC}$ closer to the erosion sources. The largest contribution to surface sediment SOC is yedoma/mineral OC that remains relatively constant over the Buor-Khaya Bay. This can probably be attributed to a strong nepheloid layer transport in the area (explained in detail by Charkin et al., 2011).

The contributions of the three fractions were also plotted versus distance to the erosion site Muostakh Island (the northernmost point) (Supplement Fig. S2), and to the distance to the Lena River mouth (Trofimovskaya river delta channel) (Supplement Fig. S3). There seemed to be no apparent association between these neither to the contributing fractions of POC nor to SOC.

\subsection{Degradation and preservation of terrestrial OM}

Despite the fact that Buor-Khaya Bay surface water POC was much younger than surface SOC (Fig. 2i and j) it carried a substantially more degraded molecular imprint (Fig. 5). This contrasts with previous studies in sub-arctic systems (e.g., van Dongen et al., 2008a; Vonk et al., 2008), but is similar to the situation recently described for the central East Siberian Sea (Vonk et al., 2010a). There is an increase in degradation imprint for surface water POC towards N/NE, with the lowest degradation observed around Muostakh Island (Fig. 5a and c). The HMW $n$-alkanoic acids/HMW $n$-alkanes ratio (individual $n$-alkanoic acids reported in Supplement Tables $\mathrm{S} 3$ and $\mathrm{S} 4$ for POC and SOC, respectively) averages 2.1 (range 0.31 to $12.6 ; n=10$ ) and $n$-alkane CPI is also low, at 0.76 on average (range 0.30 to $2.8 ; n=12$ ). These values are much lower than for surface sediment SOC where the 
Table 2. Fractional contributions to surface water POC and surface sediment SOC from plankton, active layer of surface soils and deep/old yedoma/mineral soils, as derived by Monte Carlo simulation of a three-end member mixing analysis (EMMA). The employed end-member values are listed in footnotes, and clarified with references and details in the main text (2.2.5 Monte Carlo Simulation). Results are given as mean values with standard deviations for each fraction.

\begin{tabular}{lcccccc}
\hline Surface water POC & \multicolumn{1}{l}{ Mean } & \pm & Median & Min & Max & \\
\hline & 0.19 & 0.09 & 0.17 & 0.07 & 0.32 & \\
\hline plankton OC $^{\mathrm{a}}$ & 0.63 & 0.10 & 0.71 & 0.26 & 0.83 & \\
surface soil OC $^{\mathrm{b}}$ & 0.18 & 0.06 & 0.13 & 0.03 & 0.46 & \\
yedoma/mineral soil OC $^{\mathrm{c}}$ & & & & & & YS14 \\
\hline Surface sediment SOC & & & & & & \\
\hline & Mean & \pm & Median & Min & Max & Mean \\
\hline plankton OC $^{\mathrm{a}}$ & 0.25 & 0.11 & 0.25 & 0.16 & 0.37 & 0.29 \\
surface soil OC $^{\mathrm{b}}$ & 0.14 & 0.09 & 0.14 & 0.08 & 0.20 & 0.26 \\
yedoma/mineral soil OC & 0.60 & 0.09 & 0.60 & 0.53 & 0.71 & 0.46 \\
\hline
\end{tabular}

${ }^{\text {a }}$ End-member values used: $\delta^{13} \mathrm{C}-24.0 \%$, with a standard deviation $1.0 \%$; $\Delta^{14} \mathrm{C} 25 \%$, with a standard deviation of $25 \%$. ${ }^{\mathrm{b}}$ End-member values used: $\delta^{13} \mathrm{C}-32.1 \%$, with a standard deviation $1.48 \%$; $\Delta{ }^{14} \mathrm{C}-85 \%$, with a standard deviation of $62 \%$. ${ }^{\mathrm{c}}$ End-member values used: $\delta^{13} \mathrm{C}-25.8 \%$, with a standard deviation $1.71 \%$; $\Delta \Delta^{14} \mathrm{C}-788 \%$, with a standard deviation of $201 \%$.
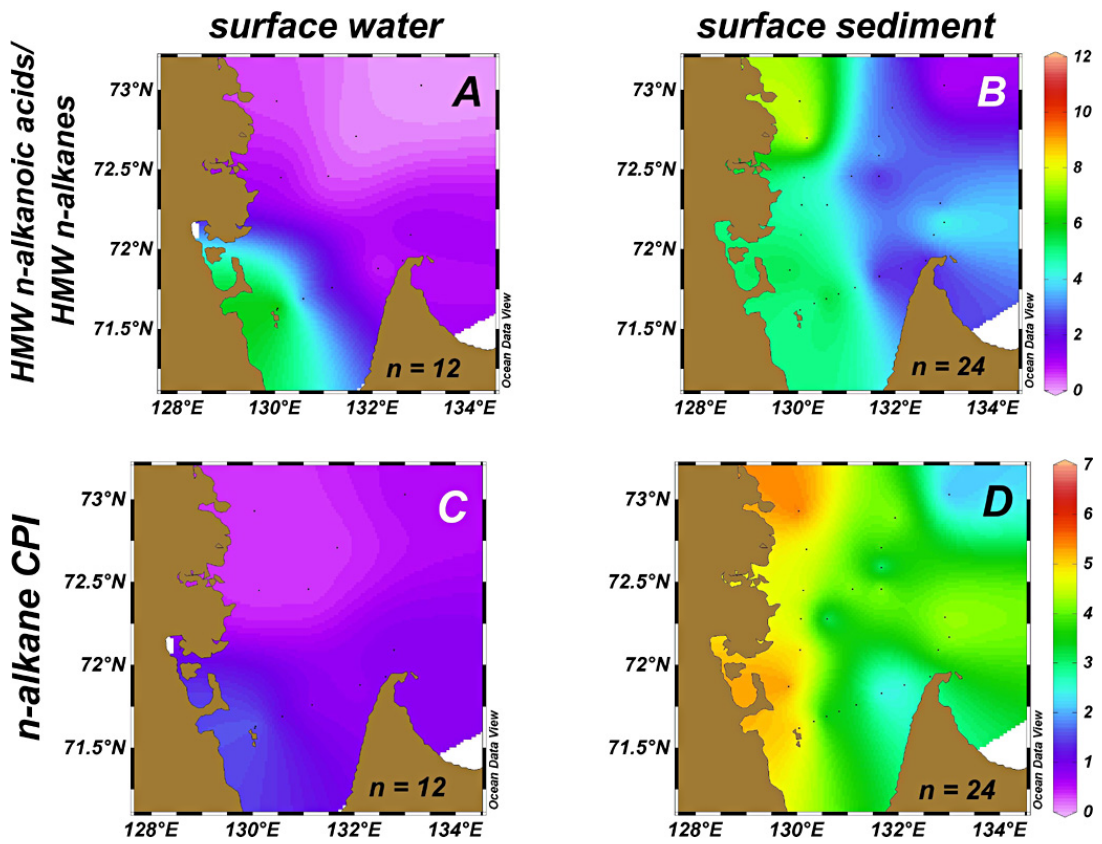

Fig. 5. Spatial distribution of organic matter degradation proxies in the Buor-Khaya Bay surface water and surface sediment in August 2008. (A) and (B) high molecular weight (HMW) i.e. the sum of chain lengths $\mathrm{C}_{20}-\mathrm{C}_{34} n$-alkanoic acids over HMW $n$-alkanes in POC and SOC, respectively; (C) and (D) $n$-alkane carbon preference index (CPI), i.e. calculated as $1 / 2 \sum\left(X_{i}+X_{i+2}+\ldots+X_{n}\right) / \sum\left(X_{i-1}+X_{i+1}+\ldots+X_{n-1}\right)+$ $1 / 2 \sum\left(X_{i}+X_{i+2}+\ldots+X_{n}\right) / \sum\left(X_{i+1}+X_{i+3}+\ldots+X_{n+1}\right)$, where $X$ is concentration.

highest degradation likewise is located to the NE, but instead the SOC reveal a very distinct WE degradation trend (Fig. 5b and d), with the highest values found near the Lena River mouth. HMW $n$-alkanoic acids/HMW $n$-alkanes values averages at 4.1 (range 0.26 to $11 ; n=23$ ) (Table 1 ). Previously reported 0.61 (van Dongen et al., 2008) from Buor-Khaya
Bay is in the low end of our range. Similarly, the carbon preference index (CPI) for $n$-alkanes in SOC average at 4.2 (range $0.41-6.3 ; n=23$ ) (Table 1 ), which signals a moderate to low degradation status. Van Dongen et al. (2008) report an $n$-alkane CPI at 5.5 in the Buor-Khaya Bay surface SOC. Both proxies indicate a sharp WE gradient for surface SOC, 
indicating a further stage of degradation around Buor-Khaya Cape and in the NE (Fig. 5b and d).

The ratio of SOC/POC for HMW $n$-alkanoic acids/HMW $n$-alkanes (Fig. 3c) as well as that for the $n$-alkane CPI (Fig. 3e) clearly indicates a dichotomy between the SOC and POC degradation patterns. On average the $n$-alkane CPI is five-fold higher for SOC than for POC. There is also a 2fold increase of HMW $n$-alkanoic acids/HMW $n$-alkanes in SOC relative to POC. The one station showing a higher degradation imprint in the SOC is located right on the NE side of the BK Cape where the $n$-alkanoic acid $/ n$-alkane ratio for the sediment is considerably lower $(0.68)$ than the average SOC (4.0). This overall more extensive degradation of surface water POC relative to the underlying SOC is surprising and to our knowledge only reported once before (Vonk et al., 2010a). However, it has also recently been suggested based on shelf-wide POC mass balance arguments that the terrestrial POC fraction both in the Laptev and East Siberian Sea undergoes extensive degradation in the water column (Sanchéz-Garcia et al., 2010), which is consistent with these biomarker patterns.

The low degradation signal in the surface SOC could be attributed to the behavior and nature of the extensive coastal erosion input. Eroded mineral-rich coastal/deltaic yedoma (a heavy, largely particulate fraction) being washed into the Buor-Khaya Bay water settles rapidly onto the bay floor, thus leaving only small traces in the water column. The high mineral component in yedoma could act as physical protection to the OC fraction of the eroded material (Keil et al., 1994; Mayer, 1994a, b). This would explain the relatively more intact (biological) production/process signals high odd-over-even predominance (CPI) and high HMW $n$ alkanoic acid/HMW $n$-alkane ratios characterizing the only moderately degraded yet very old surface SOC.

\section{Conclusions}

The Buor-Khaya Bay is the primary recipient of terrestrial OC from both river and erosion in the Laptev Sea. This detailed isotopic and molecular marker survey revealed clearly distinguished sources and degradation patterns both between surface water and surface sediments as well as with distance away from the sources over the scale of the bay. A large terrestrial input from the Lena River leaves a significant imprint on the surface water POC composition in the BuorKhaya Bay. The young fluvial/alluvial POC pool is relatively buoyant, $\mathrm{OC}$ rich and bioavailable, which is consistent with clearly resolvable spatial trends of apparently rapidly degrading POC throughout the Buor-Khaya Bay surface water. The corresponding surface SOC in contrast bears a signal from coastal erosion input and is much older yet less degraded. Strong indications towards preferential settling of coarser material along the coasts and thus short initial residence time in the water column are shown in this study by a decreasing yedoma fraction with increasing water depth. Notably, even though potentially being rather exposed to microbial degradation with a high degree of exposure due to heavy resuspension, this material shows low degradation status. These findings suggest an OC pool that quite unlike surface water POC escapes degradation through adsorption to higher density mineral particles (and subsequent steric hindrance of enzymatic cleavage) (Mayer, 1994a) derived from erosion of yedoma ice complexes. Taken together, the riverine terr-OC appears to (i) come predominantly from the annual thaw layer of the surface soil, (ii) be dominating the surface water POC and (iii) be readily degraded, whereas the coastline-erosion terr-OC is associated with minerals and therefore ballasted to the sediments where it makes up the key OC component and is relatively protected from extensive degradation.

\section{Supplementary material related to this article is available online at: http://www.biogeosciences.net/8/1865/2011/ bg-8-1865-2011-supplement.pdf.}

Acknowledgements. We thank the crew and personnel around the International Siberian Shelf Study 2008 (ISSS-08), and particularly the crew of the sub expedition onboard TB0012. The ISSS-08 campaign was supported by the Knut and Alice Wallenberg Foundation, Headquarters of the Far Eastern Branch of the Russian Academy of Sciences, the Swedish Research Council (VR Contract No. 621-2004-4039 and 621-2007-4631), the US National Oceanic and Atmospheric Administration (Siberian Shelf Study), the Russian Foundation of Basic Research (08-05-13572, 08-05-00191-a, and 07-05-00050a), the Swedish Polar Research Secretariat, the Arctic Co-Op Program of the Nordic Council of Ministers (331080-70219) and the US National Science Foundation (OPP ARC 0909546). Ö. Gustafsson also acknowledges financial support as an Academy Research Fellow from the Swedish Royal Academy of Sciences through a grant from the Knut and Alice Wallenberg Foundation, L. Sanchéz-García acknowledges a Marie Curie grant (contract no. PIEF-GA-2008-220424), and A. Andersson his support from the Knut and Alice Wallenberg Foundation. Finally we thank H. Gustafsson and Y. Zebühr at Stockholm University for instrumental and laboratory assistance.

Edited by: N. Shakhova

\section{References}

ACIA: Impacts of a Warming Arctic: Impact Assessment, 2004.

Alling, V., Sanchez-Garcia, L., Porcelli, D., Pugach, S., Vonk, J. E., van Dongen, B., Morth, C. M., Anderson, L. G., Sokolov, A., Andersson, P., Humborg, C., Semiletov, I., and Gustafsson, Ö.: Nonconservative behavior of dissolved organic carbon across the Laptev and East Siberian seas, Global Biogeochem. Cy., 24, GB4033, doi:10.1029/2010gb003834, 2010.

Anderson, L. G., Jutterstrom, S., Hjalmarsson, S., Wahlstrom, I., and Semiletov, I. P.: Out-gassing of $\mathrm{CO}_{2}$ from Siberian Shelf 
seas by terrestrial organic matter decomposition, Geophys. Res. Lett., 36, L20601, doi:10.1029/2009g1040046, 2009.

Anderson, L. G., Tanhua, T., Bjork, G., Hjalmarsson, S., Jones, E. P., Jutterstrom, S., Rudels, B., Swift, J. H., and Wahlstom, I.: Arctic ocean shelf-basin interaction: An active continental shelf $\mathrm{CO}_{2}$ pump and its impact on the degree of calcium carbonate solubility, Deep-Sea Res. Pt I , 57, 869-879, doi:10.1016/j.dsr.2010.03.012, 2010.

Antonov, V. S.: The Estuary of the Lena River: Hydrogeological Outlines, Gidrometeoizdat, Leningrad, Geophys. Res. Lett., 107, L22401, doi:10.1029/2009g1039225, 1987.

Bense, V. F., Ferguson, G., and Kooi, H.: Evolution of shallow groundwater flow systems in areas of degrading permafrost, Geophys. Res. Lett., 36, L22401, doi:10.1029/2009g1039225, 2009.

Charkin, A. N., Dudarev, O. V., Semiletov, I. P., Kruhmalev, A. V., Vonk, J. E., Sánchez-García, L., Karlsson, E., and Gustafsson, Ö.: Seasonal and interannual variability of sedimentation and organic matter distribution in the Buor Khaya Gulf - the primary recipient of input from Lena River and coastal erosion in the SE Laptev Sea, Biogeosciences Discuss., 8, 1917-1946, doi:10.5194/bgd-8-1917-2011, 2011.

Cooper, L. W., McClelland, J. W., Holmes, R. M., Raymond, P. A., Gibson, J. J., Guay, C. K., and Peterson, B. J.: Flow-weighted values of runoff tracers (delta $18 \mathrm{O}, \mathrm{DOC}, \mathrm{Ba}$, alkalinity) from the six largest Arctic rivers, Geophys. Res. Lett., 35, L18606, doi:10.1029/2008g1035007, 2008.

Dudarev, O. I., Semiletov, I. P., Botsul, A., and Charkin, A.: Modern sedimentation in the cryolitozone of the Dmitry Laptev/EastSiberian Sea, Pac. Geol., 22, 51-60, 2003.

Dudarev, O. V., Semiletov, I. P., Charkin, A. N., and Botsul, A. I.: Deposition settings on the continental shelf of the East Siberian Sea, Dokl. Earth Sci., 409, 6, 1000-1005, doi:10.1134/s1028334x06060389, 2006.

Dutta, K., Schuur, E. A. G., Neff, J. C., and Zimov, S. A.: Potential carbon release from permafrost soils of Northeastern Siberia, Glob. Change Biol., 12, 2336-2351, doi:10.1111/j.13652486.2006.01259.x, 2006.

Eglinton, G. and Hamilton, R. J.: Leaf epicuticular waxes, Science, 156, 1322-1335, 1967.

Fernandes, M. B. and Sicre, M. A.: The importance of terrestrial organic carbon inputs on Kara Sea shelves as revealed by nalkanes, OC and delta C-13 values, Org. Geochem., 31, 363-374, 2000.

Frey, K. E. and McClelland, J. W.: Impacts of permafrost degradation on arctic river biogeochemistry, Hydrol. Process., 23, 169182, doi:10.1002/hyp.7196, 2009.

Goñi, M. A., Yunker, M. B., Macdonald, R. W., and Eglinton, T. I.: The supply and preservation of ancient and modern components of organic carbon in the Canadian Beaufort Shelf of the Arctic Ocean, Mar. Chem., 93, 53-73, 2005.

Grigoryev, M. N.: Cryomorphogenesis of the Lena Delta, Yakutsk, 176 pp., 1993 (in Russian).

Grigoryev M. N. and Kunitsky, V. V.: Ice complex of the Arctic coast of Yakutia as a source of detrital deposits on the shelf, Hydrometeorological and biogeochemical researches in Arctic regions, The Arctic Areal centre, Vladivostok, Dalnauka, Issue II, part. 1, 109-116, 2000.

Gruber, N., Friedlingstein, P., Field, C. B., Valentini, R., Heimann, M., Richey, C. B., Romero-Lankao, P., Schulze, D., and Chen,
C. T. A.: The vulnerability of the carbon cycle in the 21 st century: An assessment of carbon-climate-human interactions, in: The Global Carbon Cycle: Integrating Humans, Climate and the Natural World, edited by: Raupach, R., Island Press, Washington, DC, 45-76, 2004.

Guo, L. D. and Macdonald, R. W.: Source and transport of terrigenous organic matter in the upper Yukon River: Evidence from isotope (delta C-13, Delta C-14, and delta N-15) composition of dissolved, colloidal, and particulate phases, Geophys. Res. Lett., 20, Gb2011, doi:10.1029/2005gb002593, 2006.

Guo, L. D., Ping, C. L., and Macdonald, R. W.: Mobilization pathways of organic carbon from permafrost to arctic rivers in a changing climate, Geophys. Res. Lett., 34, L13603, doi:10.1029/2007g1030689, 2007.

Guo, L. D., Semiletov, I., Gustafsson, Ö., Ingri, J., Andersson, P., Dudarev, O., and White, D.: Characterization of Siberian Arctic coastal sediments: Implications for terrestrial organic carbon export, Global Biogeochem. Cy., 18, Gb1036, doi:10.1029/2003gb002087, 2004.

Gustafsson, Ö., Haghseta, F., Chan, C., MacFarlane, J., and Gschwend, P. M.: Quantification of the dilute sedimentary soot phase: Implications for PAH speciation and bioavailability, Environ. Sci. Technol., 31, 203-209, 1997.

Gustafsson, Ö., van Dongen, B. E., Vonk, J. E., Dudarev, O. V., and Semiletov, I. P.: Widespread release of old carbon across the Siberian Arctic echoed by its large rivers, Biogeosciences, 8 , 1737-1743, doi:10.5194/bg-8-1737-2011, 2011.

IPCC: Climate Change 2007: The Physical Science Basis, Contribution of Working Group I to the Fourth Assessment Report of the Intergovernmental Panel of Climate Change, Cambridge University Press, Cambridge, UK, 2007.

Jakobsson, M., Macnab, R., Mayer, L., Anderson, R., Edwards, M., Hatzky, J., Schenke, H. W., and Johnson, P.: An improved bathymetric portrayal of the Arctic Ocean: Implications for ocean modeling and geological, geophysical and oceanographic analyses, Geophys. Res. Lett., 35(7), L07602, doi:10.1029/2008g1033520, 2008.

Keil, R. G., Montlucon, D. B., Prahl, F. G., and Hedges, J. I.: Sorptive preservation of labile organic matter in marine sediments, Nature, 370, 549-552, 1994.

Key, R. M., Kozyr, A., Sabine, C. L., Lee, K., Wanninkhof, R., Bullister, J. L., Feely, R. A., Millero, F. J. Mordy, C., and Peng, T.-H.: A global ocean carbon climatology: Results from Global Data Analysis Project (GLODAP), Global Biogeochem. Cy., 18, GB4031, doi:10.1029/2004GB002247, 2004.

MacDonald, G. M., Beilman, D. W., Kremenetski, K. V., Sheng,Y., Smith, L. C., and Velichko, A. A.: Rapid early development of circumarctic peatlands and atmospheric $\mathrm{CH} 4$ and $\mathrm{CO}_{2}$ variations, Science, 314, 285-288, doi:10.1126/science.1131722, 2006.

Mayer, L. M.: Relationships between mineral surfaces and organic carbon concentrations in soils and sediments, Chem. Geol., 114, 347-363, 1994a.

Mayer, L. M.: Surface area control of organic-carbon accumulation in continental shelf sediments, Geochim. Cosmochim. Ac., 58, 1271-1284, 1994b.

McGuire, A. D., Anderson, L. G., Christensen, T. R., Dallimore, S., Guo, L. D., Hayes, D. J., Heimann, M., Lorenson, T. D., Macdonald, R. W., and Roulet, N.: Sensitivity of the carbon cycle in 
the Arctic to climate change, Ecol. Monogr., 79, 523-555, 2009.

Naidu, A. S., Cooper, L. W., Finney, B. P., Macdonald, R. W., Alexander, C., and Semiletov, I. P.: Organic carbon isotope ratios (delta C-13) of Arctic Amerasian Continental shelf sediments, Int. J. Earth Sci., 89, 522-532, 2000.

Neff, J. C., Finlay, J. C., Zimov, S. A., Davydov, S. P., Carrasco, J. J., Schuur, E. A. G. and Davydova, A. I.: Seasonal changes in the age and structure of dissolved organic carbon in Siberian rivers and streams, Geophys. Res. Lett., 33, L23401, doi:10.1029/2006g1028222, 2006.

Overduin, P. P., Hubberten, V., Rachold, N., Romanovskii, M., Grigoriev, M., and Kasymskaya, M.: The evolution and degradataion of coastal and offshore permafrost in the Laptev and East Siberian Seas during the last climatic cycle, The Geol. Soc. Am., 426, 97-110, 2007.

Pipko, I. I., Semiletov, I. P., Pugach, S. P., Wåhlström, I., and Anderson, L. G.: Interannual variability of air-sea $\mathrm{CO}_{2}$ fluxes and carbonate system parameters in the East Siberian Sea, Biogeosciences Discuss., 8, 1227-1273, doi:10.5194/bgd-8-1227-2011, 2011.

Porcelli, D., Andersson, P. S., Wasserburg, G. J., Ingri, J., and Baskaran, M.: The importance of colloids and mires for the transport of uranium isotopes through the Kalix River watershed and Baltic Sea, Geochim. Cosmochim. Ac., 61, 4095-4113, 1997.

Rachold, V. and Hubberten, H.-W.: Carbon isotope composition of particulate organic material in East Siberian rivers, in: Landocean system in the Siberian Arctic: Dynamics and history, edited by: Kassens, H., Bauch, H. A., Dmitrenko, I. A., Eicken, H., Hubberten, H.-W., Melles, M., Thiede, J., and Timokhov, L. A., Springer-Verlag, Berlin Heidelberg, 223-237, 1999.

Rachold, V., Grigoriev, M. N., Are, F. E., Solomon, S., Reimnitz, E., Kassens, H., and Antonow, M.: Coastal erosion vs riverine sediment discharge in the Arctic Shelf seas, Int. J. Earth Sci., 89, 450-460, 2000.

Richter-Menge, J. and Overland, J. E. (Eds): Arctic Report Card 2010, available at: http://www.arctic.noaa.gov/reportcard (last access: 17 June 2011), 2010.

Romanovskii, N. N.: Bases of the Lithosphere Cryogenesis, MSU, Moscow, 1993 (in Russian).

Russell, J. M. and Werne, J. P.: The use of solid phase extraction columns in fatty acid purification, Org. Geochem., 38, 48-51, doi:10.1016/j.orggeochem.2006.09.003, 2007.

Sanchéz-García, L., Alling, V., Pugach, S., Vonk, J., van Dongen, B., Humborg, C., Dudarev, O., Semiletov, I., and Gustafsson, Ö.: Inventories and behaviour of particulate organic carbon in the Laptev and East Siberian Seas, Global Biogeochem. Cy., 25, GB2007, doi:10.1029/2010GB003862, 2011.

Sanchéz-García, L., Vonk, J., Charkin, A., Kosmach, D., Dudarev, O., Semiletov, I. P., and Gustafsson, Ö.: Remobilization and degradation of Muostakh Island (Laptev Sea) as part of collapsing Arctic coastal ice complex, in preparation, 2011.

Schirrmeister, L., Siegert, C., Kuznetsova, T., Kuzmina, S., Andreev, A., Kienast, F., Meyer, H., and Bobrov, A.: Paleoenvironmental and paleoclimatic records from permafrost deposits in the Arctic region of Northern Siberia, Quat. Int., 89, 97-118, 2002.

Schlitzer, R.: Ocean Data View, available at: http://odv.awi.de (last access: 17 June 2011).

Schuur, E. A. G., Bockheim, J., Canadell, J. G., Euskirchen, E.,
Field, C. B., Goryachkin, S. V., Hagemann, S., Kuhry, P., Lafleur, P. M., Lee, H., Mazhitova, G., Nelson, F. E., Rinke, A., Romanovsky, V. E., Shiklomanov, N., Tarnocai, C., Venevsky, S., Vogel, J. G., and Zimov, S. A.: Vulnerability of permafrost carbon to climate change: Implications for the global carbon cycle, Bioscience, 58, 701-714, doi:10.1641/b580807, 2008.

Semiletov, I. P.: Aquatic sources and sinks of $\mathrm{CO}_{2}$ and $\mathrm{CH}_{4}$ in the Polar Regions, J. Atmos. Sci., 56, 286-306, 1999a.

Semiletov, I. P.: The Failure of Coastal Frozen Rock as an Important Factor in the Biogeochemistry of the Arctic Shelf Water, Dokl. Earth Sci., 369(8), 1140-1143, 1999 b.

Semiletov, I. and Gustafsson, Ö.: East Siberian Shelf Study alleviates scarcity of observations, EOS 585 Trans., 90(145), p. 145, doi:10.1029/2009EO170001, 2009.

Semiletov, I. P., Pipko, I., Repina, I., and Shakhova, N. E.: Carbonate chemistry dynamics and carbon dioxide fluxes across the atmosphere-ice-water interfaces in the Arctic Ocean: Pacific sector of the Arctic, J. Marine Syst., 66, 204-226, 2007.

Semiletov, I., Dudarev, O., Luchin, V., Charkin, A., Shin, K.-H., and Tanaka, N.: The East Siberian Sea as a transition zone between Pacific-derived waters and Arctic shelf waters, Geophys. Res. Lett., 32, L10614, doi:10.1029/2005GL022490, 2005.

Semiletov, I. P., Pipko, I. I., Shakhova, N. E., Dudarev, O. V., Pugach, S. P., Charkin, A. N., McRoy, C. P., Kosmach, D., and Gustafsson, O.: On the biogeochemical signature of the Lena River from its headwaters to the Arctic Ocean, Biogeosciences Discuss., 8, 2093-2143, doi:10.5194/bgd-8-2093-2011, 2011.

Sidorov, I. S.: Features of forming of hydrochemical regime of mouth area of the Lena River and south east part of the Laptev Sea thesis/masters, Thesis in Geology and Mineralogy (Rostovon-Don), 24 pp., 1992.

Stein, R. and Macdonald, R.W.: The Organic Carbon Cycle in the Arctic Ocean, Springer, Berlin, Germany, 363 pp., 2004.

Tarnocai, C., Canadell, J. G., Schuur, E. A. G., Kuhry, P., Mazhitova, G., and Zimov, S.: Soil organic carbon pools in the northern circumpolar permafrost region, Global Biogeochemical Cy., 23, Gb2023, doi:10.1029/2008gb003327, 2009.

van Dongen, B. E., Semiletov, I., Weijers, J. W. H., and Gustafsson, Ö. R.: Contrasting lipid biomarker composition of terrestrial organic matter exported from across the Eurasian Arctic by the five great Russian Arctic rivers, Glob. Biogeochem. Cy., 22, Gb1011, doi:10.1029/2007gb002974, 2008a.

van Dongen, B. E., Zencak, Z., and Gustafsson, Ö.: Differential transport and degradation of bulk organic carbon and specific terrestrial biomarkers in the surface waters of a subarctic brackish bay mixing zone, Mar. Chem., 112, 203-214, doi:10.1016/j.marchem.2008.08.002, 2008b.

Vetrov, A. A. and Romankevich, E. A.: The Organic Carbon Cycle in the Russian Arctic Seas, Springer, Berlin, Germany, 331 pp., 2004.

Vonk, J. E. and Gustafsson, Ö.: Calibrating n-alkane Sphagnum proxies in sub-Arctic Scandinavia, Org. Geochem., 40, 10851090, doi:10.1016/j.orggeochem.2009.07.002, 2009.

Vonk, J. E., van Dongen, B. E. and Gustafsson, Ö.: Lipid biomarker investigation of the origin and diagenetic state of sub-arctic terrestrial organic matter presently exported into the northern Bothnian Bay, Mar. Chem., 112, 1-10, doi:10.1016/j.marchem.2008.07.001, 2008.

Vonk, J. E., Sánchez-García, L., Semiletov, I., Dudarev, O., Eglin- 
ton, T., Andersson, A., and Gustafsson, Ö.: Molecular and radiocarbon constraints on sources and degradation of terrestrial organic carbon along the Kolyma paleoriver transect, East Siberian Sea, Biogeosciences, 7, 3153-3166, doi:10.5194/bg-73153-2010, 2010a.

Vonk, J. E., van Dongen, B. E. and Gustafsson, Ö.: Selective preservation of old organic carbon fluvially released from sub-Arctic soils, Geophys. Res. Lett., 37, L11605, doi:10.1029/2010g1042909, 2010b.
Walker, H. J.: Arctic deltas, J. Coast. Res., 14, 718-738, 1998.

Xu, C. H., Guo, L. D., Ping, C. L., and White, D. M.: Chemical and isotopic characterization of size-fractionated organic matter from cryoturbated tundra soils, northern Alaska, J. Geophys. Res.-Biogeosciences, 114, G03002, doi:10.1029/2008jg000846, 2009. 